\title{
Correction: Language dysfunction-associated EEG findings in patients with CAR-T related neurotoxicity
}

Sokolov E, Karschnia P, Benjamin R, et al. Language dysfunction-associated EEG findings in patients with CAR-T related neurotoxicity. BMJ Neurol Open 2020;2:e000054. doi: 10.1136/bmjno-2020-000054.

The article has been corrected since it was published online. The published version misspelled one of the co-authors' name as Andrew Cole which has been now amended to Andrew J Cole.

Open access This is an open access article distributed in accordance with the Creative Commons Attribution Non Commercial (CC BY-NC 4.0) license, which permits others to distribute, remix, adapt, build upon this work non-commercially, and license their derivative works on different terms, provided the original work is properly cited, appropriate credit is given, any changes made indicated, and the use is non-commercial. See: http://creativecommons.org/licenses/by-nc/4.0/.

(c) Author(s) (or their employer(s)) 2020. Re-use permitted under CC BY-NC. No commercial re-use. See rights and permissions. Published by BMJ.

BMJ Neurol Open 2020;2:e000054corr1. doi:10.1136/bmjno-2020-000054corr1

A) Check for updates 